\title{
Effects of passive smoking on the health of children and adolescents: a systematic review
}

\author{
Efeitos do tabagismo passivo na saúde de crianças e adolescentes: uma revisão sistemática \\ Efectos del tabaquismo pasivo en la salud de niños y adolescentes: una revisión sistemática
}

\author{
Ana Carolina Vieira Azevedo \\ ORCID: https://orcid.org/0000-0002-7160-5862 \\ Faculdades Pequeno Príncipe, Brasil \\ E-mail: anacarolvieiraazevedo@gmail.com \\ Giulia Vittoria Ambrogi Pereira \\ ORCID: https://orcid.org/0000-0002-5230-7616 \\ Faculdades Pequeno Príncipe, Brasil \\ E-mail: giuliaambrogi@outlook.com \\ Mariana Xavier e Silva \\ ORCID: https://orcid.org/0000-0002-5841-9432 \\ Faculdades Pequeno Príncipe, Brasil \\ E-mail: mariana.silva@ fpp.edu.br \\ Kristian Sbolli \\ ORCID: https://orcid.org/0000-0001-9427-5125 \\ Prefeitura Municipal de Santana do Itararé-PR, Brasil \\ Faculdades Pequeno Príncipe, Brasil \\ E-mail: kristian.sbolli@hotmail.com \\ Elaine Rossi Ribeiro \\ ORCID: https://orcid.org/0000-0003-3492-217X \\ Faculdades Pequeno Príncipe, Brasil \\ E-mail: elaine.ribeiro@ fpp.edu.br
}

\begin{abstract}
Despite growing global efforts to control tobacco use, it remains a common addiction. Passive smoking is the inhalation of smoke from tobacco derivatives by non-smokers, breathing in the same toxic substances that the smoker inhales. The objective of this systematic review was to identify the possible effects of passive smoking on the health of children and adolescents. The PICO tool was used to prepare the research question. The protocol of this study was submitted to PROSPERO and the PRISMA guidelines were followed. The following databases were used: LILACS, MEDLINE and EMBASE. As a result, 493 articles were identified from the last 5 years, 8 articles were removed for being duplicates, 439 articles were excluded for not meeting the inclusion criteria, 8 articles were excluded for poor methodological quality and 38 were included in the study. It was concluded, as evidence, that passive smoking has negative effects on the health of children and adolescents and was associated with respiratory, infectious, psychoneurocognitive, metabolic, cardiovascular, otorhinolaryngological, allergic disorders and increased mortality.
\end{abstract}

Keywords: Long Term Adverse Effects; Systematic Review; Tobacco Smoke Pollution.

\section{Resumo}

Apesar dos crescentes esforços globais para controlar o uso do tabaco, continua a ser um vício comum. O tabagismo passivo é a inalação da fumaça de derivados do tabaco por indivíduos não fumantes, respirando as mesmas substâncias tóxicas que o fumante inala. O objetivo dessa revisão sistemática foi identificar os possíveis efeitos do tabagismo passivo na saúde das crianças e dos adolescentes. Foi utilizada a ferramenta PICO para a elaboração da pergunta pesquisa. O protocolo deste estudo foi submetido ao PROSPERO e foram seguidas as diretrizes do PRISMA. As seguintes bases de dados foram utilizadas: LILACS, MEDLINE e EMBASE. Como resultado, 493 artigos foram identificados dos últimos 5 anos, 8 artigos foram removidos por estarem duplicados, 439 artigos foram excluídos por não preencherem os critérios de inclusão, 8 artigos foram excluídos por baixa qualidade metodológica e 38 foram incluídos no estudo. Concluiu-se, como evidência, que o tabagismo passivo tem efeitos negativos na saúde de crianças e adolescentes e foi associado a afecções respiratórias, infecciosas, psiconeurocognitivas, metabólicas, cardiovasculares, otorrinolaringológicas, alérgicas e ao aumento da mortalidade.

Palavras-chave: Efeitos Adversos de Longa Duração; Revisão Sistemática; Poluição por Fumaça de Tabaco. 


\section{Resumen}

A pesar de los esfuerzos mundiales para controlar el consumo de tabaco, sigue siendo una adicción común. El tabaquismo pasivo es la inhalación de humo de derivados del tabaco por parte de no fumadores, que respiran las mismas sustancias tóxicas que inhala el fumador. El objetivo de esta revisión sistemática fue identificar los posibles efectos del tabaquismo pasivo en la salud de niños y adolescentes. Se utilizó la herramienta PICO para preparar la pregunta de investigación. El protocolo de este estudio fue presentado a PROSPERO y se siguieron las pautas PRISMA. Se utilizaron las siguientes bases de datos: LILACS, MEDLINE y EMBASE. Como resultado, se identificaron 493 artículos de los últimos 5 años, se eliminaron 8 artículos por ser duplicados, se excluyeron 439 artículos por no cumplir con los criterios de inclusión, se excluyeron 8 artículos por mala calidad metodológica y 38 se incluyeron en el estudio. Se concluyó, como evidencia, que el tabaquismo pasivo tiene efectos negativos en la salud de niños y adolescentes y se asoció con trastornos respiratorios, infecciosos, psiconeurocognitivos, metabólicos, cardiovasculares, otorrinolaringológicos, alérgicos y aumento de la mortalidad.

Palabras clave: Efectos Adversos a Largo Plazo; Revisión Sistemática; Contaminación por Humo de Tabaco.

\section{Introduction}

Smoking is defined as a chronic disease caused by addiction to nicotine present in tobacco products. Despite growing global efforts to control tobacco use, it remains a common addiction with more than 1 billion smokers worldwide, around $40 \%$ of men and 10\% of women (Öberg et al., 2011). Cigarette smoke is a mixture of about 4,720 different toxic substances such as carbon monoxide, ammonia, ketones, formaldehyde, acetaldehyde, acrolein, nicotine, and tar, many of these are known to be carcinogenic. Passive smoking is the inhalation of smoke from tobacco derivatives, it happens when non-smokers live with smokers, breathing the same toxic substances (Instituto Nacional do Câncer [INCA], 2018).

According to Matt et al. (2011), second-hand smoke is the mixture of direct smoke from burning a cigarette (or pipe/cigar) with the smoke exhaled from the smokers' lungs. Third-hand smoke is the residual pollution of tobacco smoke that remains, after burning, on surfaces and in the dust. The toxic substances can remain in common fabrics for over 1.5 years (Bahl et al., 2014). These are re-emitted to the gas phase, or they react with oxidants and other components in the environment to generate secondary pollutants. It is therefore possible to be exposed to third-hand smoke without being directly exposed to cigarette smoke (Matt et al., 2011).

The rate of exposure of children and adolescents varies between countries, as passive smoking is closely related to the rates of active smokers and public policies that prohibit indoor smoking. Worldwide, in 2011, 40\% of children were exposed to secondhand smoke indoors (Öberg et al., 2011). Children are more physiologically vulnerable and more sensitive to its harmful effects when compared to adults. Some explanations for this include the fact that their immune systems are immature, their airways are shorter and narrower, and they spend more time indoors (Boldo et al., 2010). Furthermore, they are not able to avoid the main source of exposure, their closest relatives (Öberg et al., 2011).

Secondhand smoke causes numerous health problems in children, including more severe and frequent asthma attacks, higher incidence of respiratory infections and lung dysfunction, lower respiratory tract disease, ear infections, and sudden infant death syndrome (Centers for Disease Control and Prevention [CDC], 2015). However, it is suspected that many other children and adolescent health systems are affected by passive smoking. Therefore, this study aimed to conduct a systematic review of the literature to identify the possible effects of passive smoking on the health of children and adolescents.

\section{Methodology}

This systematic review was guided by the following research question "What are the effects of passive smoking on the health of children and adolescents?". To structure the research question, the PICO tool was used, which represents an acronym for Patient, Intervention, Comparison, and Outcomes. (Santos et al., 2007). It is important to highlight that the protocol of this systematic review was submitted to PROSPERO - International prospective register of systematic review - on July 14, 2020, and 
registered under the number CRD42020159708, following the guidelines of PRISMA - Preferred Reporting Items for Systematic Reviews and Meta-Analyses (Moher et al., 2015).

The inclusion criteria were: studies with children and adolescents (a child is a person aged up to 12 years old and an adolescent is a person aged 12 to 18 years, defined by the Estatuto da Criança e do Adolescente (ECA), through Law 8069 of 1990), from any country, published in the last 5 years (2015 to 2020), in Portuguese, Spanish, and English. Articles on passive smoking in prenatal and adulthood were excluded.

The following electronic databases were used: LILACS (Literatura Latino-Americana e do Caribe emCiências da Saúde), accessed through the BVS portal, MEDLINE, accessed through the PubMed portal and EMBASE. The bibliographic search was guided by the descriptors "tabagismo", "passivo" "criança" e "adolescente" and their English counterparts "secondhand", "smoke", "children", "adolescent" ou "teenager", located in the list of the Health Sciences Descriptors, available on Portal da Biblioteca Virtual emSaúde (http://decs.bvs.br) and the Medical Subject Headings - Mesh, available on the U.S. National Library of Medicine (http://www.nlm.nih.gov/mesh/). At EMTREE the counterparts were "Passive smoking", "children, "adolescent" and "teenagers".

In the BVS e LILACS, the search key "secondhand AND smok* AND (children OR Adolescent* OR teenager*)" was used; in EMBASE, the search key "passive smoking [Title/Abstract/Keywords] AND (children[Title/Abstract/Keywords] OR adolescent* [Title/Abstract/Keywords] OR teenager*[Title/Abstract/Keywords])" was used and in PubMed, the search key “(secondhand[Title/Abstract]) AND (smok*[Title/Abstract]) AND (children[Title/Abstract] OR adolescent* [Title/Abstract] OR teenager*[Title/Abstract])" was used.

The selection of these articles was carried out in two stages: reading the titles and abstracts, reading the full article. The selection was made independently of two of the researchers based on predefined inclusion and exclusion criteria. After the selection, a consensus meeting was held for the dissenting selections and the help of the third author was also used for the tiebreaker.

The methodological quality of the selected articles was evaluated based on the criteria of Downs and Black (Downs \& Black, 1998), which guided the limitations of the articles, which allowed a critical reading of the published studies. The original questionnaire contains 27 questions, divided into four groups: presentation (evaluates items such as clarity in the description of objectives, confounding variables, probability values); external validity (related to the extrapolation of data to the population from which the sample was planned); internal validity (bias analysis, reliability of exposure and outcome measures, and use of confounding variables); and power of the study.

To use this questionnaire in this study, questions $8,13,14,15,23,24$, and 27 were removed because they referred to clinical trial studies, and all articles obtained were observational. Each question generated a score that allowed us to objectively evaluate the articles. Therefore, the articles could reach a maximum score of 21 , considering that question 5 has a score of 2 . To consider an article with good scientific evidence, a score of 11 or more was adopted in the Downs and Black classification.

The analysis was carried out by direct reading of the articles in English by the authors. As a synthesis strategy, a table was designed using the Microsoft Office Word program, with the general characteristics of the selected articles: authors, year of publication, country and database found, sample and age group, type of study, and Downs and Black score.

\section{Results}

According to flowchart 1 below, the search based on the descriptors in the selected databases led to the identification of 493 potential articles for inclusion in the systematic review. 8 duplicate articles were identified. The main characteristics of the excluded articles were theme with another subject, they analyzed other pollutants, only epidemiological analysis on passive smoking, analysis only on legislation related to passive smoking, analysis of passive smoking in prenatal care and in adulthood. 
Flowchart 1 - Selection of articles in different databases.

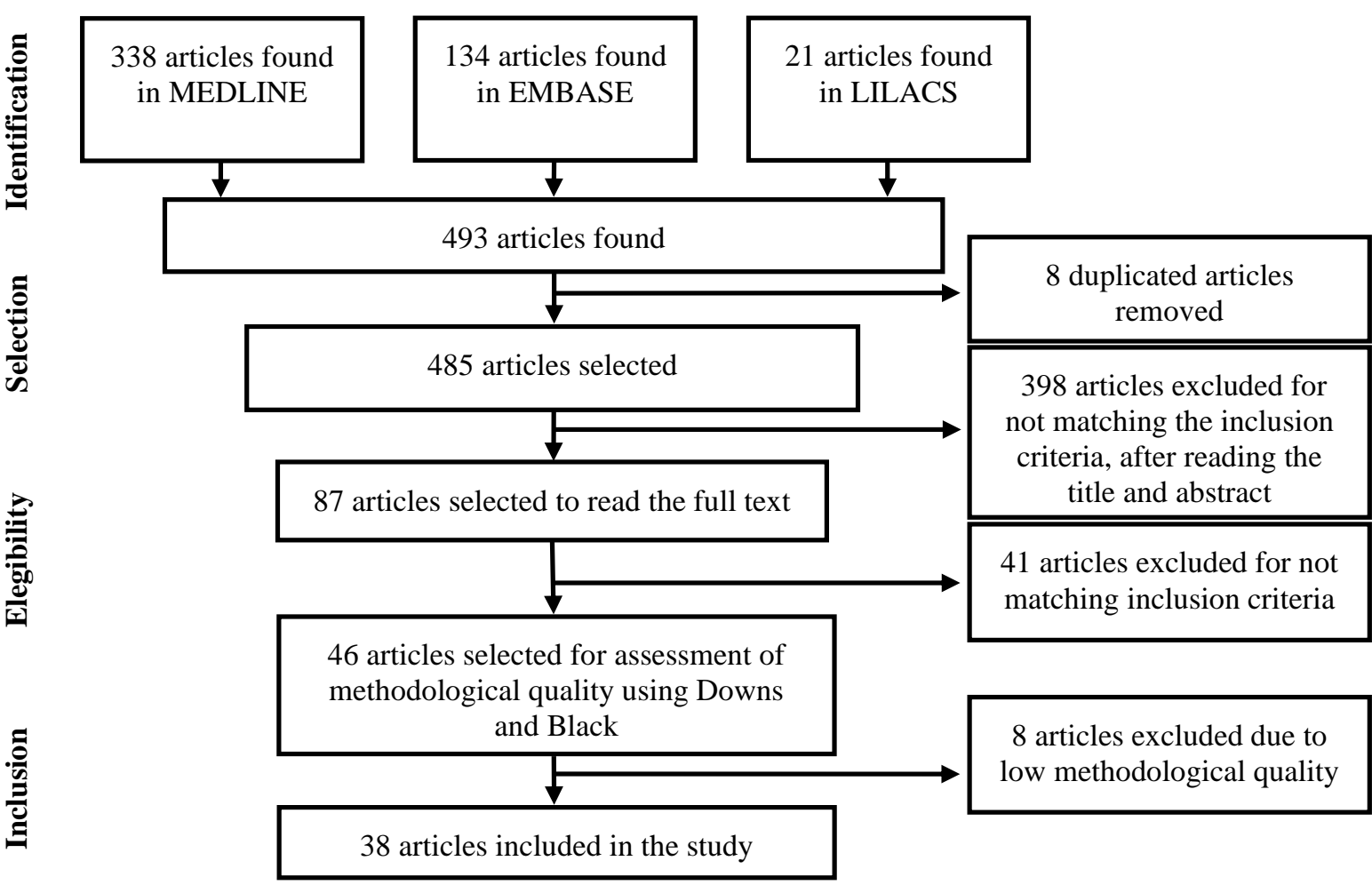

Source: authors (2020).

Articles with the analysis of children and adolescents who actively smoke were found and after consensus was excluded for not answering the research question of this review. 46 articles were selected for the assessment of methodological quality. 8 articles with less than 11 on the Downs and Black score were evaluated with low methodological quality and were excluded. 38 studies were included, of which 71.7\% $(n=28)$ were from MEDLINE, 28.2\% $(n=11)$ from EMBASE. No articles were selected from the LILACS database. The correspondence of the articles with the database where it was found can be seen in Table 1 .

Table 1 - Characteristics of the Articles.

\begin{tabular}{|c|c|c|c|c|c|c|}
\hline Authors & Year & País & Database & Sample and age group & $\begin{array}{l}\text { Type of } \\
\text { Study }\end{array}$ & $\begin{array}{c}\text { Downs and } \\
\text { Black }\end{array}$ \\
\hline 1. LEUNG, L. T. et al & 2016 & China & Medline & 61810 students aged 6 to 12 years & $\mathrm{CS}$ & 13 \\
\hline 2. CHEN, Z. et al & 2018 & China & Medline & 3575 students aged 14 to 16 years & CS & 12 \\
\hline $\begin{array}{l}\text { 3. SIGAUD, C. H. S.; } \\
\text { CASTANHEIRA, A. } \\
\text { B. C.; COSTA, P }\end{array}$ & 2016 & Brazil & Medline & $\begin{array}{l}215 \text { parents and caregivers of children } \\
\text { aged } 4 \text { months to six years and two } \\
\text { months }\end{array}$ & CS & 11 \\
\hline $\begin{array}{l}\text { 4. JING, W.; WANG, } \\
\text { W.; LIU, Q. }\end{array}$ & 2019 & China & Embase & $\begin{array}{l}378 \text { children aged } 3 \text { to } 12 \text { years with } \\
\text { asthma }\end{array}$ & $\mathrm{CS}$ & 11 \\
\hline 5. PYLE, R. C. et al & 2015 & USA & Medline & $\begin{array}{l}944236 \text { cases and } 708 \text { controls aged } 5 \\
\text { to } 18 \text { years }\end{array}$ & $\mathrm{CC}$ & 14 \\
\hline $\begin{array}{l}\text { 6. FEDELE, D. A. et } \\
\text { al }\end{array}$ & 2016 & USA & Medline & $\begin{array}{l}305 \text { smokers caregivers of children up } \\
\text { to } 17 \text { years with asthma }\end{array}$ & CS & 13 \\
\hline
\end{tabular}




\begin{tabular}{|c|c|c|c|c|c|c|}
\hline $\begin{array}{l}\text { 7. MERIANOS, A. L.; } \\
\text { JANDAROV, R. A.; } \\
\text { MAHABEE- } \\
\text { GITTENS, E. M }\end{array}$ & 2018 & USA & Medline & $\begin{array}{l}2198 \text { asthmatic adolescents, between } \\
12 \text { and } 17 \text { years old }\end{array}$ & $\mathrm{CS}$ & 12 \\
\hline $\begin{array}{l}\text { 8. HASSANZAD, M; } \\
\text { et al }\end{array}$ & 2015 & Iran & Embase & 100 patients under 10 years of age & CS & 12 \\
\hline 9. YILMAZ, O. et al & 2017 & Turkey & Medline & $\begin{array}{l}150 \text { children with recurrent wheezing } \\
\text { aged } 1 \text { to } 3 \text { years }\end{array}$ & CS & 13 \\
\hline $\begin{array}{l}\text { 10. ADETIFA, I. M. } \\
\text { O. et al }\end{array}$ & 2017 & Gambia & Medline & $\begin{array}{l}718 \text { Children and adolescents } \leq 14 \\
\text { years pulmonary } \mathrm{TB}\end{array}$ & $\mathrm{CS}$ & 12 \\
\hline 11. FUJITA, T. et al & 2019 & Japan & Medline & 5743 children, aged 0 to 3 years & $\mathrm{CS}$ & 13 \\
\hline 12. SUZUKI, S. et al & 2015 & Japan & Embase & 597 elementary school students II & $\mathrm{CS}$ & 12 \\
\hline 13. WANG, H. et al & 2019 & China & Medline & 17571 children aged 6 to 13 years & $\mathrm{CS}$ & 12 \\
\hline 14. PADRÓN, A. et al & 2016 & Spain & Medline & 2357 children aged 4 to 12 years & CS & 14 \\
\hline 15. BANG, I, et al & 2017 & $\begin{array}{l}\text { South } \\
\text { Korea }\end{array}$ & Medline & 62,708 adolescents aged 12 to 18 years & $\mathrm{CS}$ & 13 \\
\hline $\begin{array}{l}\text { 16. PAGANI L. S. et } \\
\text { al }\end{array}$ & 2017 & Canada & Medline & 1035 children aged 1.5 to 7 years & $\mathrm{C}$ & 17 \\
\hline 17. HUANG, J. et al & 2018 & China & Medline & $\begin{array}{l}3575 \text { with an average age of } 15.0 \pm 1.8 \\
\text { years }\end{array}$ & $\mathrm{CS}$ & 13 \\
\hline 18. KIM, N. H. et al & 2016 & $\begin{array}{l}\text { South } \\
\text { Korea }\end{array}$ & Medline & 989 adolescents on average of 15 years & $\mathrm{CS}$ & 13 \\
\hline $\begin{array}{l}\text { 19. WELLMAN, R. J. } \\
\text { et al }\end{array}$ & 2020 & Canada & Medline & 1553 adolescents aged 16 to 18 years & $\mathrm{C}$ & 18 \\
\hline $\begin{array}{l}\text { 20. ABDEL HAMED, } \\
\text { N. A. et al }\end{array}$ & 2019 & Egypt & Medline & 100 children aged 4 to 12 years & $\mathrm{CC}$ & 12 \\
\hline 21. LUK, T. T. et al & 2018 & China & Medline & $\begin{array}{l}301 \text { non-smoking mothers with their } \\
\text { children aged } \leq 18 \text { months }\end{array}$ & $\mathrm{CS}$ & 14 \\
\hline 22. WADA, K. et al & 2020 & Japan & Embase & 459 children aged 3 to 6 years & $\mathrm{CS}$ & 14 \\
\hline $\begin{array}{l}\text { 23. PAGANI, L. S. e } \\
\text { FITZPATRICK, C. }\end{array}$ & 2016 & Canada & Medline & 2,055 children aged 1.5 to 7 years & $\mathrm{C}$ & 14 \\
\hline 24. CHEN, J. J. et al & 2015 & China & Medline & $\begin{array}{l}1238 \text { students with a mean age of } 8.5 \\
\pm 0.9 \text { years }\end{array}$ & CS & 13 \\
\hline 25. TORUN, E. et al & 2019 & Turkey & Medline & $\begin{array}{l}71 \text { children and adolescents aged } 4 \text { to } \\
17 \text { years }\end{array}$ & $\mathrm{CS}$ & 12 \\
\hline $\begin{array}{l}\text { 26. KAHRAMAN, F. } \\
\text { U. et al }\end{array}$ & 2016 & Turkey & Medline & $\begin{array}{l}40 \text { children and adolescents aged } 5 \text { to } \\
17 \text { years }\end{array}$ & $\mathrm{CS}$ & 12 \\
\hline $\begin{array}{l}\text { 27. GRONER, J. A. et } \\
\text { al }\end{array}$ & 2016 & USA & Medline & $\begin{array}{l}86 \text { children and adolescents aged } 9 \text { to } \\
18 \text { years }\end{array}$ & $\mathrm{CS}$ & 11 \\
\hline
\end{tabular}




\begin{tabular}{|c|c|c|c|c|c|c|}
\hline $\begin{array}{l}\text { 28. LOFFREDO, L. et } \\
\text { al }\end{array}$ & 2018 & Italy & Embase & $\begin{array}{l}114 \text { children with an average age of } \\
8.7 \text { years }\end{array}$ & $\mathrm{CS}$ & 12 \\
\hline $\begin{array}{l}\text { 29. MAHABEE- } \\
\text { GITTENS, E. M.; et al }\end{array}$ & 2019 & USA & Medline & 112 patients aged 0 to 17 years & $\mathrm{CS}$ & 12 \\
\hline $\begin{array}{l}\text { 30. GRONER, J. A. et } \\
\text { al }\end{array}$ & 2017 & USA & Medline & 139 children aged 2 to 5 years & $\mathrm{CS}$ & 14 \\
\hline $\begin{array}{l}\text { 31. EBRAHIMI, M. el } \\
\text { al }\end{array}$ & 2019 & Iran & Embase & 4200 students 7 to 18 years & $\mathrm{CS}$ & 13 \\
\hline 32. ZHANG, Z. et al & 2019 & China & Embase & $\begin{array}{l}42,745,000 \text { children and adolescents } \\
\text { aged } 7 \text { to } 18 \text { years }\end{array}$ & $\mathrm{CS}$ & 15 \\
\hline $\begin{array}{l}\text { 33. TAHIR, E.; } \\
\text { KAVAZ, E.; YASAR, } \\
\text { O. C. }\end{array}$ & 2020 & Turkey & Embase & $\begin{array}{l}125 \text { children and adolescents from } 3 \text { to } \\
16 \text { years }\end{array}$ & $\mathrm{CS}$ & 11 \\
\hline $\begin{array}{l}\text { 34. DURANTE, A. S. } \\
\text { et al }\end{array}$ & 2017 & Brazil & Embase & 90 children 10 years old & $\mathrm{CS}$ & 11 \\
\hline $\begin{array}{l}\text { 35. BHANDARY, S. } \\
\text { et al }\end{array}$ & 2016 & India & Embase & 100 children aged 5 to 13 years & $\mathrm{CS}$ & 13 \\
\hline 36. KIM, J. et al & 2018 & $\begin{array}{l}\text { South } \\
\text { Korea }\end{array}$ & Medline & 16676 children from 1 to 13 years & $\mathrm{CS}$ & 12 \\
\hline $\begin{array}{l}\text { 37. LOFFREDO, L. et } \\
\text { al }\end{array}$ & 2018 & Italy & Embase & $\begin{array}{l}65 \text { children with allergic rhinitis and } \\
65 \text { controls }\end{array}$ & $\mathrm{CS}$ & 15 \\
\hline 38. OWILI, P. O. et al & 2017 & Taiwan & Medline & 787,484 children under the age of five & $\mathrm{CS}$ & 13 \\
\hline
\end{tabular}

Legend: "CS" means that the study is of the Cross-sectional type, "CC" type Case-Control and "C" of the Cohort type. Source: produced by the authors (2020).

\section{Discussion}

In face of the scenario that was found and considering the number of articles analyzed, the subjects of the articles were divided into different categories, which will be presented below:

\subsection{Respiratory Conditions}

Leung, Ho, Wang, \& Lam (2018) applied a questionnaire adapted from GYTS (Global Youth Tobacco Survey) to more than 60,000 students aged 6 to 12 from 79 randomly selected Hong Kong schools. As a result, the authors said that exposure to second-hand smoke at home, from neighbors, and third-hand smoke were linearly associated with respiratory symptoms.

Respiratory symptoms were defined as persistent cough or expectoration for 3 consecutive months during the last 12 months in the study by Chen et al. (2018). This cross-sectional study, with age participants including adolescents, explores exposure to secondary passive smoking in public places and in schools, in addition to indoor exposure that is the focus of the above study. The authors reported that there was a significant increase in the risk of having respiratory symptoms to passive exposure to secondary smoking in public places, in homes, indoor sands and in outdoor school fields, using no exposure as a reference. 
A Brazilian survey of 215 parents and caregivers of children aged 4 months to six years and two months of age from 5 Early Childhood Education centers, conducted by Sigaud, Castanheira, \& Costa (2016), defined respiratory symptoms such as cough, wheezing, rapid breathing, pain or secretion in the ear and subdiaphragmatic retraction in the last 3 months. Despite the difference in definition with the previous article, they associate passive smoking at home with the higher occurrence of rapid breathing and subdiaphragmatic retraction. In addition, they tried to associate passive smoking with respiratory morbidities (pneumonia, bronchiolitis, treated ear diseases/ear infections/otitis, bronchitis or asthma) and hospitalization for any respiratory problem at least once in their life. They obtained a negative association, only otitis treated with positive association in their results.

Jing, Wang \& Liu (2019) recruited 378 children diagnosed with asthma from a Chinese University hospital and graduated the severity of the disease from 1 to 4 using the Definitions of the European Respiratory Society/American Thoracic Society guidelines. They used a questionnaire to define and quantify (in number of cigarettes) exposure to passive smoking. To measure this exposure, they also used the level of cotinine in the urine of these children. Cotinine is a metabolite and biomarker of nicotine that can provide information about the duration of passive exposure to cigarette smoke. They also measured immunological factors with ELISA kits. What they obtained was that cotinine levels in urine and serum IgE levels increased significantly from grade 1 to grade 4 asthma. Passive smoking worsens asthma with the higher number of cigarettes smoked indoors and increased serum IgE levels. As asthma severity increased, there was an increase in Type 17 T-helper cells (Th17) and decreased T-regulatory cells (Treg), a pathophysiological mechanism associated with the induction of increased asthma severity in children by passive smoking.

Pyle et al. (2015) were successful in identifying comorbidities and understanding the use of health services in children and adolescents with asthma exposed to secondhand smoke, compared to those who were not exposed. Study participants were identified from the PAMP - Pediatric Asthma Management Program database. The survey results were: participants who were exposed to secondhand smoke had higher body mass percentiles, had fewer tests for asthma such as methacholine challenge and an exhaled nitric oxide, forced expiratory volume in one second and the ratio of this to capacity vital were lower and were less likely to have received influenza vaccination.

They were included in the study by Fedele et al. (2016), 53 Latin Americans and 84 African-American smokers parents and caregivers of children with asthma up to 17 years. A questionnaire was answered by the participants, with data on asthma severity and variables on smoking. It was dosed with Hammond Sampler, a nicotine dosimeter that shows traces of nicotine in the air, for passive smoking, which were left in the participants' homes for 7 to 10 days, both in the room in which the child was more and trapped in the child's clothes. To complete the study, the parents received the amount of 25 dollars. The results showed a great relationship between the exposure of passive smoking and the severity of asthma, African Americans had higher nicotine concentrations and had lower statistics of smoking bans indoors.

A cross-sectional study was conducted by Merianos, Jandarov \& Mahabee-Gittens (2019) based on the longitudinal Population Assessment of Tobacco and Health (PATH) study conducted in the US by the National Institutes of Health and Food and Drug Administration. They included adolescents with asthma and nonsmokers and found through statistical analyses that those exposed to passive smoking were at higher risk of having asthma symptoms, of using asthma control medications, and more likely to use an emergency department.

Hassanzad et al. (2015) selected 100 children with asthma, 50 of them were exposed to smoking and 50 who were not exposed. A questionnaire on asthma symptoms was completed by parents and asthma severity was determined according to the Global Initiative For Asthma (GINA). They measured cotinine with ELISA kits in urine, blood and saliva samples from all children. The results found were that severe and moderate asthma, cotinine levels in urine, blood and saliva were significantly higher in the group exposed to passive smoking. 
Yilmaz et al. (2017) conducted a study in Turkey with 150 children aged 1 to 3 years who had recurrent wheezing. They defined recurrent wheezing as the presence of 3 or more episodes of wheezing diagnosed by physicians. The scores of wheezing symptoms were higher in children exposed to passive smoking. The article also attempts to associate other markers such as IgE, SP-D and nicotine level in blood samples and glutathione, IL-8, IL-17, MMP-9, and TIMP-1 in samples of nowasing, but none showed significant association with passive smoking and the occurrence of wheezing.

\subsection{Infectious Conditions}

Adetifa et al. (2017) investigate the additional risk of M. tuberculosis infection, due to childhood exposure to passive smoking from contacts infected with tuberculosis, through a cross-sectional study with children under 14 years of age. It has been discovered that exposure to passive smoking by a case of tuberculosis acts as an effect modifier, which can further increase the risk of M. tuberculosis infection in children.

Data from 5,743 children between 0 and 3 years old, Fujita, Babazono, Harano, \& Jiang (2019) evaluated the influence of passive smoking on the incidence of streptococcal infection. They concluded that passive smoking significantly increased the incidence of this type of infection.

The association between exposure to passive smoking and the occurrence of modified measles was analyzed by Suzuki, Sato, Watanabe, Nezu, \& Nishimuta (2015), in a cohort of 513 elementary school II students in Japan, through the use of a questionnaire survey and urinary cotinine measurement. Modified measles is one that occurs in previously immunized individuals. The study revealed a higher incidence of disease development among students living with people who smoked indoors. In addition, in urinary analysis, a high level of urinary cotinine was associated with an increased risk of modified measles after immunization.

\subsection{Psychoneurocognitive Conditions}

In their study, Wang, Li, Zhang, Jiang, \& Zhang (2019) explored the association between exposure to secondhand smoke and psychological symptoms in 17571 children aged 6 to 13 years. Psychological symptoms were assessed by the parental version of the Strengths and Difficulties Questionnaire (SDQ). The study supports previous studies showing that children who were exposed to any duration of secondhand smoke had a higher risk of having psychological symptoms and their specific domains regarding emotional symptoms, behavior problems, attention deficit hyperactivity disorder, peer relationship problems and pro-social behaviors than those not exposed.

In this cross-sectional study, Padrón et al. (2016) examined the association between exposure to secondhand smoking in the household and mental health in children. The study used data from 2357 children, representative of the Spanish population aged 4 to 12 years. The duration of secondhand smoking exposure in children was parent-reported and the likely mental disorder was defined as a score > 90th percentile on the parent version of the Strengths and Difficulties Questionnaire (SDQ). Children who were exposed to secondhand smoke in the household showed a higher frequency of mental disorders, specifically ADHD, than those who were not exposed or who had only sporadic exposure.

The association between secondhand smoke exposure and mental health-related variables such as depression, stress and suicide was investigated by Bang et al. (2017) in 62,708 participants from Seoul, South Korea (30,964 boys and 31,744 girls), aged 12 to 18 years. The results for the secondhand smoke group compared to the unexposed group suggest that secondhand smoke is associated with depression, stress, suicidal ideation, suicide planning, and suicide attempt, with this association increasing with greater exposure to secondhand smoke.

Pagani, Lévesque-Seck, Archambault, \& Janosz (2017), through a prospective longitudinal study, tried to examine the association between early childhood cigarette smoke exposure in 1035 children between the ages of 1.5 to 7 years and later 
reported antisocial behavior at age 12. The data were taken from the Quebec Longitudinal Study birth cohort and the children were followed up on a biennial basis. In early childhood, youth who grew up in homes characterized by secondhand smoke showed an increased risk of later inciting aggression toward other children and threatening violence. Increased risks were also found for using reactive aggression to solve problems in situations related to sharing, teasing and discussing differences of opinion. In addition, there was also an association with a proportionally increased risk of engaging in early delinquent behavior, such as missing classes, fighting, trespassing, being questioned by police officers and being associated with a gang. At school, children exposed to early family secondhand smoke had a higher risk of poor academic performance, failing subjects and disliking school by the end of sixth grade. There was also a link with not liking school as much as their unexposed peers. Finally, increased exposure to secondhand smoke also predicted more exaggerated behavior in the classroom, such as disruptiveness, insolence and dissimulation.

Dose-response links between secondhand smoke exposure and depressive symptoms were explored by Huang et al. (2018) among 3575 nonsmoking students in Guangzhou, China, with a mean age of $15.0 \pm 1.8$ years. Depressive symptoms were measured using the Center for Epidemiological Studies Depression Scale. It was found that there was a monotonic increase in frequency-risk relationship between environment-specific secondhand smoke exposure (public places, homes, or indoor/outdoor campuses) and severity-specific depressive symptoms (probable or severe), i.e., regular exposure to secondhand smoke is associated with a significant, dose-dependent increase in the risk of depressive symptoms among adolescents.

Kim, Park, Choi, Lee, \& Kim (2016) aimed to assess the association between exposure to secondhand smoke and depressive symptoms among 989 Korean adolescents aged 15 years on average. Depressive symptoms were assessed according to the Beck Depression Inventory (BDI), ranging from 0 to 63, and the presence of depressive symptoms was defined as a BDI score $\geq 10$ and participants were classified into three groups according to severity: normal (0 to 9$)$, mild (10 to 15$)$, and moderate to severe (16 to 63). A significant association was found between exposure to secondhand smoke and depressive symptoms among male adolescents. In female adolescents, no amount of exposure to secondhand smoke was significantly associated with depressive symptoms. Further studies are needed to clarify the relevant biological or psychological mechanisms, as well as the potential reasons for differential associations between the genders.

In this longitudinal study, Wellman et al. (2020) also investigate whether exposure to secondhand smoke is associated with depressive symptoms in a sample of 1553 non-smoking children and adolescents in grades 5-11 (16-18 years). To obtain these data, 29 French-speaking elementary schools in Greater Montreal, Canada, were followed from grades 5-11 (2005-11) in 5 waves: (1 (5th grade), 2 (6th grade), 3 (7th grade), 4 (9th grade), and 5 (11th grade)). Exposure to secondhand smoke, whether in the household or in cars was found to be associated with depressive symptoms in the short term (i.e., contemporaneously or up to a year later), but not in the long term.

Hamed, Hammad, Salama, Yassa, \& Awaga (2020), nesse estudo caso-controle, investigam a associação potencial entre a exposição ao fumo passivo e TDAH em 100 crianças de 4 a 12 anos, que foram divididas nos grupos estudados: (grupo I) 70 crianças com TDAH e o grupo de controle (grupo II) 30 crianças saudáveis. O TDAH foi considerado quando diagnosticado por pediatras e psicólogos, utilizando os critérios do DSM IV. A seleção das crianças foi feita aleatoriamente na clínica ambulatorial do Hospital da Criança da Universidade de Assiut. Os dados foram coletados por um questionário para avaliar a exposição domiciliar ao tabagismo passivo e a coleta de amostras de sangue para medição de cotinina sérica como um indicador de exposição ao tabagismo passivo a curto prazo. A exposição ao tabagismo passivo e a sua duração de acordo com a exposição domiciliar relatada (tanto hora/dia como ano) foram significativamente mais elevadas no grupo TDAH em comparação com o grupo controle. Foi concluído que existe uma associação significativa entre TDAH na amostra examinada de crianças e a exposição ao tabagismo passivo. 
The association of secondhand smoke exposure during early childhood with behavioral health at preschool age was examined by Luk et al. (2018) in this prospective cohort study. Data were collected from 301 non-smoking mothers with their children aged $\leq 18$ months, visiting postpartum primary care clinics in Hong Kong. Saliva was collected for the cotinine assay and the children's behavioral health at the 3-year follow-up period was assessed by the Strengths and Difficulties Questionnaire (SDQ), answered by parents. Higher cotinine concentrations during childhood were associated with greater behavior problems and ADHD in preschool age. This study supports previous findings on the potential role of secondhand smoke in the development of childhood behavioral problems. In addition, the study also considered maternal depressive symptoms, which contribute to both childhood exposure to secondhand smoke and behavioral outcomes. A strong bivariate association was observed between maternal depressive symptoms and child behavioral problems. However, it is also possible that the child's behavioral problems may contribute to or exacerbate maternal mental health problems.

This behavioral relationship was also examined by Wada et al. (2020), who evaluated the associations between secondhand smoke exposure and behavioral problems in 437 Japanese children, aged 3 to 6 years, through a questionnaire answered by parents and measurement of urinary cotinine concentrations. The children's behavior was assessed with the Japanese version of the Strengths and Difficulties Questionnaire (SDQ). The study demonstrated positive dose-response associations between current and cumulative exposure to reported secondhand smoke in the household and behavioral problems among the children. Higher urinary cotinine concentrations were also associated with more behavioral problems.

Pagani \& Fitzpatrick (2016) looked to estimate the prospective association between prolonged exposure to tobacco smoke in the household from infancy through the end of first grade and subsequent teacher-reported student engagement in the classroom at the end of fourth grade (10 years). 2,055 children aged 1.5 to 7 years were included in the study. Parents of children participating in the Quebec Longitudinal Study of Child Development reported home smoking by themselves and other occupants of the house. At age 10, fourth grade teachers reported the child's student engagement in the classroom. 58\% of parents reported that their children were never exposed to tobacco smoke in the house, while $34 \%$ and $8 \%$ of children were exposed to transient and continuous smoke, respectively. Compared to the never-exposed children, those who were exposed to transient and continuous household smoke scored 13\% and 9\% lower standard deviation in classroom engagement in fourth grade. Compared to their never-exposed peers, children exposed to transient and continuous home smoking in early childhood showed proportionally less engagement in the classroom, which reflects task orientation, following directions, and working well independently and with others. This predisposition carries risks for high school dropout, which, from a population health perspective, is closely linked to high-risk lifestyle habits and harmful outcomes.

Associations between family member smoking and exposure to secondhand smoke at home with family unhappiness were investigated by Chen, Ho, Au, Wang \& Lam (2015), using cross-sectional data from 1238 elementary school students (mean age 8.5 years) in Hong Kong. These students reported family smoking, exposure to secondhand smoke at home, and whether their families had any unpleasant experiences caused by smoking or secondhand smoke in the past 30 days (tobaccorelated unpleasant experience) and rated the overall level of happiness in their families. Unpleasant tobacco-related experiences and family unhappiness were reported by $27.5 \%$ and $16.5 \%$ of students, respectively. Unpleasant experiences were more strongly associated with family smoking than exposure to secondhand smoke at home. Family unhappiness was associated with family smoking and exposure to secondhand smoke at home. These results suggest a possible previously overlooked impact of tobacco use on family happiness.

\subsection{Metabolic Conditions}

The effects of secondhand smoke on lipids and oxidative stress-associated parameters (catalase, thiol, and MPO myeloperoxidase levels) were evaluated by Torun et al. (2019), in 24 girls and 17 boys between 4 and 17 years of age, who had 
been exposed to tobacco smoke (at least five cigarettes per day) during the last 6 weeks prior to inclusion in the study. The control group consisted of 12 boys and 18 girls within the same age range, but not subject passively exposed to cigarette smoke. Passive smoking was confirmed by measuring the cotinine/creatinine ratio. A variety of sociodemographic characteristics of the patients were recorded. The levels of catalase, thiol, myeloperoxidase were measured to determine the antioxidant and oxidant levels in the children, while the levels of total cholesterol and LDL cholesterol were measured to determine the changes in the lipid profile. Serum levels of the antioxidants thiol and catalase did not differ between the study and control groups, while myeloperoxidase levels were higher in the former group. This shows that the oxidative balance in children exposed to passive smoking shifts toward the pro-oxidant state and suggests that oxidant levels are affected before changes in antioxidants can be observed. Given the previous studies in this field, it is clear that passive exposure to cigarette smoke could cause the development of serious diseases in these children leading to increased morbidity and mortality.

Loffredo et al. (2018), meanwhile, explored oxidative stress by analyzing nicotinamide adenine dinucleotide phosphate oxidase-2 (Nox2) activity and endothelial function, using data from 57 children, with a mean age of 8.7 years, exposed to secondhand smoke. 57 control children were used for comparison. The level and type of exposure were measured by questionnaires answered by both parents. Serum cotinine levels were assessed in the children to measure exposure to secondhand smoke. The results provide the first evidence that Nox2-derived oxidative stress is higher in children exposed to passive smoking and is closely related to the degree of exposure.They also found an increase in isoprostanes, which are bioactive products of lipid peroxidation that cause vasoconstriction and eventually endothelial dysfunction.

Groner et al. (2016) also investigated the relationships between secondhand smoke exposure and oxidative stress in a group 86 healthy, non-smoking youth and adolescents aged 9 to 18 years with high body mass index. Three quarters of the participants were either overweight or obese. Exposure to secondhand smoke was determined by survey and hair nicotine level. Markers of oxidation were total antioxidant capacity, malondialdehyde (MDA) protein adducts, and measurement of lipid peroxidation in serum. Lipid peroxidation is a well-established mechanism of cellular injury and is used as an indicator of oxidative stress in cells and tissues. There was a significant relationship between MDA and the three survey questions about smoking exposure (smoking mother, smoker living in the house and number of smokers in the house). There was a significant positive relationship between hair log-nicotine and MDA, which remained significant after controlling for age, sex, race, and health insurance choice. Total antioxidant capacity was related to only one survey question (number of smokers in the house). Therefore, a significant positive relationship of hair nicotine and MDA was demonstrated in a group of young people with a high proportion of overweight/obese people. Because youth who are exposed to secondhand smoke have an increased risk of becoming smokers, they also have an increased risk of having multiple cumulative risk factors for developing cardiovascular disease in adulthood.

The effect of secondhand smoke on serum antioxidants, oxidative status, and paraoxonase- 1 levels in 40 children and adolescents passively exposed to cigarette smoke (verified by urine cotinine levels), aged 5-17 years, compared to 40 age-and sex-matched, healthy controls, who were not regularly exposed to cigarette smoke was examined by Kahraman, Torun, Osmanoglu, Oruçlu, \& Ozer (2017). Total antioxidant status, total oxidant status, and serum paraoxonase-1 levels were all measured and the oxidative stress index was calculated for each child to indicate the degree of oxidative stress. Urine cotinine levels were significantly higher in the secondhand smoke group compared to controls, but serum TAS (total antioxidant status) levels were not statistically different between the two groups $(\mathrm{p}=0.767)$. Serum TOS (total oxidant status) and OSI (oxidative stress index) levels were significantly higher and paraoxonase-1 activity was significantly lower in the passive smoker group.

Mahabee-Gittens, Merianos, Fulkerson, Stone, \& Matt (2019) examined the prevalence of environmental tobacco smoke (ETS) exposure and its relationship to cytokine levels in a sample of 112 patients aged 0-17 years who were hospitalized in general pediatric medical units. Inflammatory markers (IL-8, IL-1 $\beta$, IL-10 and TNF- $\alpha$ ) and cotinine were measured in the 
saliva of the hospitalized children. To assess the association between environmental tobacco smoke exposure and immune system response, a multivariate regression model was constructed including the four inflammatory markers as response variables and cotinine, age, sex, and discharge diagnosis as explanatory variables while assessing possible interaction effects. Regardless of diagnosis, there was a significant association between cotinine and IL-1 $\beta$, reflecting no association for cotinine levels $<5 \mathrm{ng} / \mathrm{mL}$ and a positive association for $>5 \mathrm{ng} / \mathrm{mL}$. Children with higher levels of environmental tobacco smoke exposure had higher IL$1 \beta$ levels, regardless of age, sex, and diagnosis. In conclusion, environmental tobacco smoke exposure may increase proinflammatory immune responses in children and may interfere with native immune responses and the ability to heal and fight infection.

\subsection{Cardiovascular Conditions}

Groner et al. (2017) investigated, in 139 children aged 2 and 5 years, the association of preclinical markers of cardiovascular risk that are established and relevant in the adult population with exposure to passive smoking (measured with nicotine level in the hair). The positive associations were related to the percentage of blood systolic pressure and CRP, and had an inversely proportional relationship with total cholesterol and HDL.

Ebrahimi et al. (2019) used data from CASPIAN-V, iran's fifth national noncommunicable disease surveillance study, and evaluated 4,200 students aged 7 to 18 years, randomly chosen but maintaining the equal number in gender and between provinces, and the proportional number between urban and rural areas and each grade. They applied an approved questionnaire to students and their parents about physical activity, screen time and passive smoking. They measured height, weight, waist and abdominal circumference, waist, blood pressure. A blood sample was also collected. The results found in this research show that metabolic syndrome and overweight range were statistically higher in students who were exposed to passive smoking. No statistically significant associations were found with waist, neck circumference, low HDL-C, high LDL-C, high triglyceride and high cholesterol.

Data from 42,745 participants aged 7 to 18 from a Chinese national project evaluating the effectiveness of an obesity prevention lifestyle program in children and adolescents were used by Zhang et al. (2019). They measured the weight, height and blood pressure of these participants and applied a questionnaire with demographic information, physical exercises, eating patterns. Another questionnaire was applied to parents about smoking, education and disease in the family. As a result they found that in the girls in the survey, exposure by at least one of the smoking parents had a positive association with their blood pressure. A second statistical analysis was made to adjust some confounding factors and the association remained positive. Exposed girls were also 1.11 more likely to have hypertension compared to non-exposed girls. A statistical analysis was performed with subgroups of girls separately, first subgroup ( 7 to 12 years) and second subgroup (13 to 18 years), and the results continued the same. According to them, active smokers are rarer in younger children, so findings from these subgroups would be less likely to be affected by active smoking. No association between exposure and blood pressure was found in boys. One possible explanation, according to them and their findings, is that the girls were physically less active than the boys and could spend more time indoors, exposed.

\subsection{Otorhinolaryngological Conditions}

Tahir, Kavaz \& Yasar (2020) recruited 125 healthy children aged 3 to 16 for their studies, these were relatives of patients admitted to a tertiary otorhinolaryngology referral center. A translated and validated form of the Turkish instrument PVRQoL, which measures voice-related quality of life, was given to parents. The aim of this study was to relate passive smoking with dysphonia, because voice health is directly affected by the respiratory system. The result presented of the overall voice quality 
was statistically lower in children exposed to passive smoking. Dysphonia in children, according to them, can generate communication and cognition difficulties and cause learning problems and psychological dysfunctions.

Durante et al. (2017), recruited 90 children from a public school to participate in the study, they were tested with a basic audiology assessment and passive smoking was measured with the determination of cotinine concentration in the urine by the ELISA test. The teachers also answered a questionnaire with information about academic performance. They found that the higher the cotinine level found in the first urine of school-age children, the higher the temporal resolution limit and the lower the percentage of correct answers in the GIN (Gap in noise) test. Only children exposed to smoke presented medium difficulties, indicating that smoke exposure can negatively impact school performance. According to the article, temporal processing is the ability to process acoustic signals such as speech and music and this ability is essential in understanding speech in children and has an impact on school performance.

A survey of 50 children exposed to passive smoking and 50 who were not exposed was conducted by Bhandary, Rao, Shetty \& D'Cruz (2016). The children were approached with their parents in the waiting room for dental treatment at the A.B. Shetty Memorial Institute of Dental Sciences in India. A questionnaire on smoking was completed by the parents and a saliva sample of the children was collected. The results of the study showed a lower salivary $\mathrm{pH}$ and flow rate with an increase in amylase activity and bufferability in passive smoking children when compared to healthy children. However, sialic acid levels did not show significant differences between exposed and non-exposed children. According to them, any factor that influences the rate of secretion or composition of saliva will eventually increase susceptibility to cavities.

\subsection{Allergic Conditions}

In order to investigate the relationship between passive smoking and allergic symptoms in children living in homes with multiple units, Kim, Lee, Lee \& Kim (2019) conducted a study. They used the official Korean ISAAC questionnaire to identify the prevalence of wheezing, rinitis and eczema in the last 12 months. A questionnaire was applied to children with demographic questions and how often they smelled tobacco that entered their living space from somewhere else or around their building during the period of 12 previous months. The results found were that children living in homes exposed to passive smoking were statistically more likely to have wheezing, rinitis and eczema in the last 12 months than those who lived in unexposed homes.

Loffredo et al. (2018) conducted a survey of 65 children affected by severe and persistent allergic rhinitis to mites and with 65 healthy children. At selection, patients with rinitis should not be on antiallergic treatment for at least 4 weeks. All participants were submitted to ultrasound evaluation of flow-mediated dilation of the brachial artery and had blood collected for oxidative stress markers analysis (NADPH oxidase activity by means of blood level measurements of soluble NOX2 peptide derivative "sNOX2-dp", isoprostans, NO) and evaluation of plasma cotinine, which identifies exposure to passive smoking. Parents answered a questionnaire about smoking, including time and place of exposure. The results found were that, compared to healthy controls, children with persistent allergic rhinitis had significantly higher levels of sNOX2-dp and isoprostanes, lower flow-mediated dilation and reduced nitric oxide bioavailability. Serum sNOX2-dp levels were significantly higher in children with allergic rhinitis exposed to smoke compared to children with allergic rhinitis not exposed.

\subsection{Mortality}

Data from children 78748423 African countries were used to develop a cross-sectional study by Owili, Muga, Pan, \& Kuo (2017). The countries included were: Benin $(n=42,775)$, Bukina Faso $(n=53,312)$, Burundi $(n=23,209)$, Comores $(n=$ 9,870), Congo ( $n=28,379)$, Côte d'Ivoire $(n=25,312)$, DRC $(n=56,391)$, Ethiopia $(n=42,849)$, Gab $(n=17,882)$, Gambia $(n$ $=23,980)$, Guinea $(\mathrm{n}=25,873)$, Kenya $(\mathrm{n}=36,947)$, Liberia $(\mathrm{n}=27,263)$, Mali $(\mathrm{n}=28,125)$, Mozambique $(\mathrm{n}=34,766)$, Nigeria 
( $\mathrm{n}=114,134)$, Namibia $(\mathrm{n}=9,259)$, Rwanda $(\mathrm{n}=30,597)$, Sierra Leone $(\mathrm{n}=43,471)$, Togo $(\mathrm{n}=25,084)$, Uganda $(\mathrm{n}=27,748)$, Zambia $(n=43,064)$ and Zimbabwe $(n=17,194)$. These countries were considered due to the availability of the most recent data on secondhand smoke indoors. The results indicate that passive smoking increases the risk of mortality of children under five years of age in sub-Saharan Africa. In addition, this effect was greater in children living in rural areas.

Among the selected articles, only longitudinal ones, such as "Cohort" and "Case-Control", can establish with greater assertiveness the causal relationship between these effects and passive smoking, because these types of observational studies analyze a longer period of time, which occurs in Pyle et al., (2015), Pagani \& Fitzpatrick (2016), Pagani, Lévesque-Seck, Archambault, \& Janosz (2017), Hamed, Hammad, Salama, Yassa, \& Awaga (2020) and Wellman et al., (2020). Articles with cross-sectional method cannot affirm the causal association of passive smoking with such effects, only indicate pure association or prevalence, but this does not cancel its importance as an instrument for the presentation of vulnerable populations and for health realization and planning (Bastos \& Duquia, 2007).

In addition, cotinine measurement, due to the short half-life time, evaluates short-term exposure, demonstrating only recent exposures. (Hamed et al., 2020). In some studies, smoking data were collected by questionnaires and then biochemical cotinine measurements were also collected to confirm passive smoking.

\section{Conclusion}

This systematic review aimed to identify the possible effects of passive smoking on the health of children and adolescents and, it can be pointed out as evidence that passive smoking causes negative effects on the health of children and adolescents, being associated with respiratory, infectious, psychoneurocognitive, metabolic, cardiovascular, entrine, allergic and increased diseases of mortality.

There are limitations in articles in which data on exposure to passive smoking were self-reported, both by children and young people and by parents. Those who offer biochemical measures can provide more concrete and reliable data. However, these measures do not make it possible to distinguish sources of exposure.

It is expected that, with the data of this article, passive smoking can be treated as a serious risk factor for various health problems, serving as inspiration for the creation of new public health policies focused on this theme, and monitoring existing policies, seeking to strengthen legislation that deals with the subject and creating new ways to raise awareness among the population about its harms, parents, who are unaware of the effects of passive smoking on their children's health.

Pediatricians, in general, consider the theme relevant, but it is strongly indicated, after compiling the evidence of this review, that educational actions have to be used with parents, family members and children, also with the multidisciplinary team that monitors family health.

We suggest that readers and health researchers can continue to seek evidence on this topic, especially by investigating the children themselves and their health problems, to determine a framework based on the findings of this study.

It can be pointed out that the strengths of this review are: the diversity of publications by several countries, the diversity of effects associated with passive smoking and the use only of articles with high methodological quality. Limitations include: the use of articles published only in the last 5 years and exclusion of articles with evidence of the age group of children and adolescents, but which also included adults and/or pregnant women.

Finally, it is important to highlight the sayings

Not even ventilation and air cleaning systems are effective in preventing exposure to components present in cigarette smoke, the only measure to eliminate exposure to passive smoking in nonsmokers is to totally prevent active smoking in indoor spaces. (Figueiró et al., 2016, p.9) 
There are no conflicts of interest.

\section{References}

Adetifa, I. M. O., Kendall, L., Donkor, S., Lugos, M. D., Hammond, A. S., Owiafe, P. K., Hill, P. C. (2017, Aug). Mycobacterium tuberculosis Infection in Close Childhood Contacts of Adults with Pulmonary Tuberculosis is Increased by Secondhand Exposure to Tobacco. Am. J. Trop. Med. Hyg., 97(2).

Bahl, V., Iii, P. J., Havel, C., Schick, S. F., \& Talbot, P. (2014, Oct). Thirdhand Cigarette Smoke: Factors Affecting Exposure and Remediation. PLOS ONE, $9(10)$.

Bang, I., Jeong, Y., Park, Y., Moon, N., Lee, J., \& Jeon, T. (2017, Aug). Secondhand Smoking Is Associated with Poor Mental Health in Korean Adolescents. Tohoku Journal of Experimental Medicine, 242(4), 317 -326.

Bastos, J. L. D., \& Duquia, R. P. (2007, Dec). Um dos delineamentos mais empregados em epidemiologia: estudo transversal. Scientia Medica, 17(4), 229 232 .

Bhandary, S., Rao, S., Shetty, S., \& D’Cruz, A. M. (2016, Apr). Estimation of salivary biomarkers in passive smoking children - a comparative study. Bangladesh Journal of Medical Science, 15(2), $160-165$.

Boldo, E., Medina, S., Öberg, M., Puklová, V., Mekel, O., Patja, K., Posada, M. (2010, May). Health Impact Assessment of Environmental Tobacco Smoke in European Children: Sudden Infant Death Syndrome and Asthma Episodes. Public Health Reports, $125(3), 478$ - 487.

Centers for Disease Control and Prevention [CDC] (2018). Health Effects of Secondhand Smoke. From https://www.cdc.gov/tobacco/datastatistics/factsheets/secondhandsmoke/healtheffects/

Chen, J. J., Ho, S. Y., Au, W. M., Wang, M. P., \& Lam, T. H. (2015, Nov). Family Smoking, Exposure to Secondhand Smoke at Home and Family Unhappiness in Children. International Journal of Environmental Research and Public Health, 12(11), 14557 - 14570.

Chen, Z., Liu, G., Chen, J., Li, S., Jiang, T., Xu, B., \& Ye, X. (2018, Apr). Frequency-risk relationships between second-hand smoke exposure and respiratory symptoms among adolescents: a cross-sectional study in South China. BMJ Open, 8(4).

Downs, S. H., \& Black, N. (1998, Jun). The feasibility of creating a checklist for the assessment of the methodological quality both of randomised and nonrandomised studies of health care interventions. Journal of Epidemiology and Community Health, $52(6), 377$ - 384.

Durante, A. S., Massa, B., Pucci, B., Gudayol, N., Gameiro, M., \& Lopes, C. (2017, Jun). Effect of passive smoking on auditory temporal resolution in children. International Journal of Pediatric Otorhinolaryngology, 97, 18 - 23.

Ebrahimi, M., Aghdam, M. H., Qorbani, M., Kaboodan, F. A., Shafiee, G., Khatami, F., Heshmat, R. (2019, Aug). Passive smoking and cardiometabolic risk factors in Iranian children and adolescents: CASPIAN-V study. Journal of Diabetes and Metabolic Disorders, $18(2), 401-408$.

Farias, F., Milaneis, F., Lopes, F., Campos, N., Soares, T., Staniszewski, T., \& Chong-Silva, D. C. (2015). Approach of passive smoking by Brazilian pediatricians. European Respiratory Journal, 46(suppl 59).

Fedele, D. A., Tooley, E., Busch, A., McQuaid, E. L., Hammond, S. K., \& Borrelli, B. (2016, Feb). Comparison of secondhand smoke exposure in minority and nonminority children with asthma. Health Psychology: Official Journal of the Division of Health Psychology, American Psychological Association, $35(2), 115$ $-122$

Figueiró, L. R., Ziulkoski, A. L., Dantas, D. C. M., Figueiró, L. R., Ziulkoski, A. L., \& Dantas, D. C. M. (2016, Nov). Thirdhand smoke: when the danger is more than you can see or smell. Cadernos de Saúde Pública, 32(11).

Fujita, T., Babazono, A., Harano, Y., \& Jiang, P. (2019, Jun). Secondhand Smoke and Streptococcal Infection in Young Children Under Japan's Voluntary Tobacco-Free Policy. Population Health Management, 22(3), 272 - 277.

Groner, J. A., Huang, H., Eastman, N., Lewis, L., Joshi, M. S., Schanbacher, B. L., Bauer, J. A. (2016, Jul). Oxidative Stress in Youth and Adolescents With Elevated Body Mass Index Exposed to Secondhand Smoke. Nicotine \& Tobacco Research : Official Journal of the Society for Research on Nicotine and Tobacco, $18(7), 1622-1627$

Groner, J. A., Huang, H., Joshi, M. S., Eastman, N., Nicholson, L., \& Bauer, J. A. (2017, Oct). Secondhand Smoke Exposure and Preclinical Markers of Cardiovascular Risk in Toddlers. Journal of Pediatrics, 189, $155-161$.

Hamed, N. A. A., Hammad, E. E. M., Salama, R. H., Yassa, H. A., \& Awaga, M. M. (2020). Secondhand smoke as a risk factor for attention deficit hyperactivity disorder in children. Inhalation Toxicology, 31(11-12), $420-427$.

Hassanzad, M., Khalilzadeh, S., Nobari, S. E., Bloursaz, M., Sharifi, H., Mohajerani, S. A., Velayati, A. A. (2015, Feb). Cotinine level is associated with asthma severity in passive smoker children. Iranian Journal of Allergy, Asthma, and Immunology, 14(1), 67 - 73.

Huang, J., Xu, B., Guo, D., Jiang, T., Huang, W., Liu, G., \& Ye, X. (2018, May). Relationships between SecondHand Smoke Exposure and Depressive Symptoms among Adolescents in Guangzhou, China. International Journal of Environmental Research and Public Health, 15(5).

Instituto Brasileiro de Geografia e Estatística [IBGE] (2013). Pesquisa Nacional de Saúde. From ftp://ftp.ibge.gov.br/PNS/2013/pns2013.pdf

Instituto Nacional de Câncer [INCA] (2018). Tabagismo Passivo. From https://www.inca.gov.br/tabagismo/tabagismo-passivo 
Instituto Nacional de Câncer [INCA] (2019). Dados e Números da Prevalência do Tabagismo. From https://www.inca.gov.br/observatorio-da-politica-nacionalde-controle-do-tabaco/dados-e-numeros-prevalencia-tabagismo

Jing, W., Wang, W., \& Liu, Q. (2019, Mar). Passive smoking induces pediatric asthma by affecting the balance of Treg/Th17 cells. Pediatric Research, 85(4), $469-476$.

Kahraman, F. U., Torun, E., Osmanoglu, N. K., Oruçlu, S., \& Ozer, O. F. (2017, Jan). Serum oxidative stress parameters and paraoxonase-1 in children and adolescents exposed to passive smoking. Pediatrics International: Official Journal of the Japan Pediatric Society, 59(1), 68 - 73.

Kim, J., Lee, E., Lee, K., \& Kim, K. (2019, Mar). Relationships Between Secondhand Smoke Incursion and Wheeze, Rhinitis, and Eczema Symptoms in Children Living in Homes Without Smokers in Multi-Unit Housing. Nicotine \& Tobacco Research : Official Journal of the Society for Research on Nicotine and Tobacco, $21(4), 424-429$.

Kim, N. H., Park, J. H., Choi, D. P., Lee, J. Y., \& Kim, H. C. (2016, Dec). Secondhand Smoke Exposure and Depressive Symptoms among Korean Adolescents: JS High School Study. PloS One, 11(12).

Leung, L. T., Ho, S. Y., Wang, M. P., \& Lam, T. H. (2018, Jan). Secondhand Smoke From Multiple Sources, Thirdhand Smoke and Respiratory Symptoms in Hong Kong Adolescents. Nicotine \& Tobacco Research : Official Journal of the Society for Research on Nicotine and Tobacco, 20(2), $192-198$.

Loffredo, L., Zicari, A. M., Occasi, F., Perri, L., Carnevale, R., Angelico, F., Violi, F. (2018, Oct). Role of NADPH oxidase-2 and oxidative stress in children exposed to passive smoking. Thorax, 73(10), $986-988$.

Loffredo, L., Zicari, A. M., Occasi, F., Perri, L., Carnevale, R., Battaglia, S., Violi, F. (2018, Nov). Passive Smoking Exacerbates Nicotinamide-Adenine Dinucleotide Phosphate Oxidase Isoform 2-Induced Oxidative Stress and Arterial Dysfunction in Children with Persistent Allergic Rhinitis. Journal of Pediatrics, 202, $252-257$.

Luk, T. T., Wang, M. P., Suen, Y. N., Koh, D. S., Lam, T. H., \& Chan, S. S. (2018, Oct). Early childhood exposure to secondhand smoke and behavioural problems in preschoolers. Scientific Reports, $8(1)$.

Mahabee-Gittens, E. M., Merianos, A. L., Fulkerson, P. C., Stone, L., \& Matt, G. E. (2019, Nov). The Association of Environmental Tobacco Smoke Exposure and Inflammatory Markers in Hospitalized Children. International Journal of Environmental Research and Public Health, 16(23).

Matt, G. E., Quintana, P. J. E., Destaillats, H., Gundel, L. A., Sleiman, M., Singer, B. C., Hovell, M. F. (2011, Sep). Thirdhand Tobacco Smoke: Emerging Evidence and Arguments for a Multidisciplinary Research Agenda. Environmental Health Perspectives, 119(9), 1218 - 1226.

Merianos, A. L., Jandarov, R. A., \& Mahabee-Gittens, E. M. (2019, Apr). Association of secondhand smoke exposure with asthma symptoms, medication use, and healthcare utilization among asthmatic adolescents. Journal of Asthma : Official Journal of the Association for the Care of Asthma, 56(4), 369 - 379.

Moher, D., Shamseer, L., Clarke, M., Ghersi, D., Liberati, A., Petticrew, M., Whitlock, E. (2015, Jan). Preferred reporting items for systematic review and metaanalysis protocols (PRISMA-P) 2015 statement. Systematic Reviews, 4(1).

Öberg, M., Jaakkola, M. S., Woodward, A., Peruga, A., \& Prüss-Ustün, A. (2011, Jan). Worldwide burden of disease from exposure to second-hand smoke: a retrospective analysis of data from 192 countries. Lancet, 377(9760), $139-146$.

Owili, P. O., Muga, M. A., Pan, W., \& Kuo, H. (2017, May). Indoor secondhand tobacco smoke and risk of under-five mortality in 23 sub-Saharan Africa countries: A population based study and meta-analysis. PloS One, 12(5).

Padrón, A., Galán, I., García-Esquinas, E., Esteve Fernández, Ballbè, M., \& Rodríguez-Artalejo, F. (2016, May). Exposure to secondhand smoke in the home and mental health in children: a population-based study. Tobacco Control, 25(3), $307-312$

Pagani, L. S., \& Fitzpatrick, C. (2016, Oct). Early Childhood Household Smoke Exposure Predicts Less Task-Oriented Classroom Behavior at Age 10. Health Education \& Behavior : the Official Publication of the Society for Public Health Education, 43(5), 584 - 591.

Pagani, L. S., Lévesque-Seck, F., Archambault, I., \& Janosz, M. (2017, May). Prospective longitudinal associations between household smoke exposure in early childhood and antisocial behavior at age 12. Indoor Air, 27(3), $622-630$.

Pyle, R. C., Divekar, R., May, S. M., Narla, N., Pianosi, P. T., Hartz, M. F., Joshi, A. Y. (2015, Sep). Asthma-associated comorbidities in children with and without secondhand smoke exposure. Annals of Allergy, Asthma \& Immunology : Official Publication of the American College of Allergy, Asthma, \& Immunology, 115(3), $205-210$

Ribeiro, F. A., de Moraes, M. K. R., de Morais Caixeta, J. C., da Silva, J. N., Lima, A. S., Parreira, S. L. S., \& Fernandes, V. L. S. (2015, Dec). Perception of parents about second hand smoke on the health of their children: an ethnographic study. Revista Paulista de Pediatria, 33(4), 394 - 399.

Sigaud, C. H., de Couto Castanheira, A. B., \& Costa, P. (2020). Association between secondhand smoking in the home and respiratory morbidity in preschool children. Revista Da Escola De Enfermagem Da USP, 50(4), 562 - 568.

Suzuki, S., Sato, K., Watanabe, H., Nezu, Y., \& Nishimuta, T. (2015, Nov). Environmental tobacco exposure is associated with vaccine modified measles in junior high school students. J. Med. Virol., 87(11), $1853-1859$.

Tahir, E., Kavaz, E., \& Yassar, O. C. (2020, Mar). The Effect of Parental Smoking on Voice-Related Quality of Life in the Pediatric Population. Journal of Voice : Official Journal of the Voice Foundation, S0892-1997(20), 30060 - 30066.

Torun, E., Kahraman, F. U., Goksu, A. Z., Vahapoglu, A., \& Cakin, Z. E. (2019, May). Serum catalase, thiol and myeloperoxidase levels in children passively exposed to cigarette smoke. Italian Journal of Pediatrics, 45(1).

Wada, K., Ueyama, J., Konishi, K., Goto, Y., Koda, S., Mizuta, F., Nagata, C. (2020, May). Associations between Exposure to Tobacco Smoke and Behavioral Problems in Preschool Japanese Children. Journal of Environmental and Public Health, 2020. 
Research, Society and Development, v. 10, n. 13, e582101321275, 2021

(CC BY 4.0) | ISSN 2525-3409 | DOI: http://dx.doi.org/10.33448/rsd-v10i13.21275

Wang, H., Li, F., Zhang, Y., Jiang, F., \& Zhang, J. (2019, Jul). The association between exposure to secondhand smoke and psychological symptoms among Chinese children. BMC Public Health, 19(1), $923-$.

Wellman, R. J., Wilson, K. M., O’Loughlin, E. K., Dugas, E. N., Montreuil, A., \& O’Loughlin, J. (2020, Jan). Secondhand Smoke Exposure and Depressive Symptoms in Children: A Longitudinal Study. Nicotine \& Tobacco Research : Official Journal of the Society for Research on Nicotine and Tobacco, 22(1), 32 -39 .

Yilmaz, O., Turkeli, A., Onur, E., Bilge, S., \& Yuksel, H. (2018, May). Secondhand tobacco smoke and severity in wheezing children: Nasal oxidant stress and inflammation. Journal of Asthma : Official Journal of the Association for the Care of Asthma, 55(5), 477 - 482.

Zhang, Z., Ma, J., Wang, Z., Dong, Y., Yang, Z., Dong, B., \& Ma, Y. (2019, Apr). Parental smoking and blood pressure in children and adolescents: a national cross-sectional study in China. BMC Pediatrics, 19(1). 